Original Article

\title{
Metal Complexes of $\pi$-Expanded Ligands (4): Synthesis and Characterizations of Copper(II) Complexes with a Schiff Base Ligand Derived from Pyrene
}

\author{
Luong Xuan Dien ${ }^{1,2, *}$, Nguyen Xuan Truong ${ }^{1}$, Ken-ichi Yamashita ${ }^{2}$, \\ Ken-ichi Sugiura ${ }^{2}$ \\ ${ }^{1}$ Hanoi University of Science and Technology, No.1 Dai Co Viet, Hanoi, Vietnam \\ ${ }^{2}$ Graduate School of Science and Engineering, Tokyo Metropolitan University, \\ 1-1 Minami-Ohsawa, Hachi-Oji, Tokyo 192-0397, Japan
}

Received 31 December 2019

Revised 22 February 2020; Accepted 23 February 2020

\begin{abstract}
An innovative $\pi$-expanded ligand derived from salicylaldimine ligand representing pyrene ring as a substitute for benzene ring was synthesized in 5 steps from commercially available pyrene. This unique bidentate ligand (1) was coordinated to $\mathrm{Cu}(\mathrm{II})$ metal centre for affording complex 2, which was characterized by IR, elemental, X-ray diffraction analyses, and magnetic susceptibility. Its coordination geometry is a trans-square plane with an obvious stair-step structure which is formed by two pyrene moieties and the coordination plane $\left(\mathrm{CuN}_{2} \mathrm{O}_{2}\right)$. In addition, the dihedral angle between the coordination plane and the pyrene ring is $34.9^{\circ}$ and the plane of seven carbon atoms of the long alkyl chains were arranged nearly parallel to the pyrene rings. The electronic properties of this novel complex 2 were examined via cyclic voltammetry and absorption spectroscopy to show the narrower HOMO-LUMO gap than those of the complex 4 . Moreover, the particular behavior of both complexes $\mathbf{2}$ and $\mathbf{4}$ was investigated through DFT studies.
\end{abstract}

Keywords: Coordination chemistry, Copper, Pyrene, $\pi$-Expanded ligand, Salicylaldimine.

\footnotetext{
* Corresponding author.

Email address: dien.luongxuan@ @ust.edu.vn

https://doi.org/10.25073/2588-1140/vnunst.4983
} 


\section{Introduction}

Salicylaldimine is one type of the Schiff based ligands containing an NO chelate binding for complexation with most of the transition metals such as $\mathrm{Pt}^{2+}, \mathrm{Pd}^{2+}, \mathrm{Cu}^{2+}, \mathrm{Ni}^{2+}, \mathrm{Zn}^{2+}$ etc. So far, many salicylaldiminato-type ligands and their complexes have been reported. These complexes have been employed as catalysts $[1,2]$, metallomesogens [3,4], organic lightemitting devices (OLEDs) $[5,6]$. These useful applications in the industry have encouraged us to continue the development of salicylaldiminato-type metal complexes. Among strategies to improve their properties, ligand modification is a noticeable method [7,8].

Pyrene is a popular $\pi$-electronic rich aromatic hydrocarbon and concurrently one of the most widely studied organic chromophores. Its photophysical properties, such as excimer emission, a long fluorescence lifetime, and high quantum yield have been an engaging subject in fundamental and applied researches [9]. Therefore, pyrene-based complex of the salicylaldiminato-type ligand would be likely to establish a new type of ligand with striking photophysical properties. In addition, we have been put endeavors to study crystal structures and properties of donor-acceptor charge-transfer complexes for application in organic solar cells in which metal complexes as $\pi$-electron donor moieties based on the large conjugated systems are expected to boost electrochemical and photophysical properties [10-13].

Many studies on pyrene-based complexes have been documented in which the pyrene behaves as a pendant to a common ligand [14$20]$ or organometallic pyrene complexes $[19,21$ 24]. The salicylaldiminato-type ligands of pyrene have already been utilized to prepare for sensors and organic light-emitting diodes [25]. However, as far as we know, there exist few reports on salicylaldiminato-type transitionmetal complexes of pyrene [26-29]. In this paper, we have demonstrated that the expansion of the $\pi$ electronic system of ligand can generate significant changes in the electronic, photophysical, and structural properties of the salicylaldiminato-type copper(II) complex 2.

\section{Results and Discussion}

\subsection{Synthesis and MS Analysis}

The syntheses of the ligand (1) and the corresponding copper(II) complex (2) are shown in Scheme 1 [30]. $\mathrm{Cu}(\mathrm{OAc})_{2}$ and the ligand 1 was heated in a solvent mixture of toluene and ethanol in the presence of a base, $\mathrm{CH}_{3} \mathrm{COONa}$, at $60^{\circ} \mathrm{C}$ for 3 hours under ambient atmosphere. The complex 2 was purified by chromatography using silica gel or by filtering directly from a mixture of the cooled reaction solution and a large amount of cold methanol to remove acetate salts.

The addition of base is crucial to prevent 1 from being decomposed in an acid environment that is created when adding metal cation into the solution. 2 was obtained from the reaction mixture as a yellow solid with a high yield of $\sim 86$ $\%$. It should be noted that the new complex $\mathbf{2}$ is stable under ambient condition and/or toward usual manipulations such as silica-gel chromatography and recrystallization from hot solvents, e.g., boiling ethyl acetate, under the air and room light. The reference complex 4 was prepared according to the literature reported for the similar complex having another alkyl group [31-35].

After being purified by recrystallization, the copper(II) complex $\mathbf{2}$ went through analysis by mass spectroscopy (MS) as shown in Figure S1 of the Supporting Information (SI). The parent peak was observed by MS at $\mathrm{m} / \mathrm{z} 776.34\left[\mathrm{M}^{+}\right]$, while $\mathrm{m} / \mathrm{z} \quad 776.34$ was calculated for $\mathrm{C}_{50} \mathrm{H}_{52} \mathrm{~N}_{2} \mathrm{O}_{2} \mathrm{Cu}$. The theoretical value and the experimental value are perfectly consistent (Figure S1 in the SI). Additionally, all compounds were also characterized by elemental analysis (Figure S2 in the SI). 

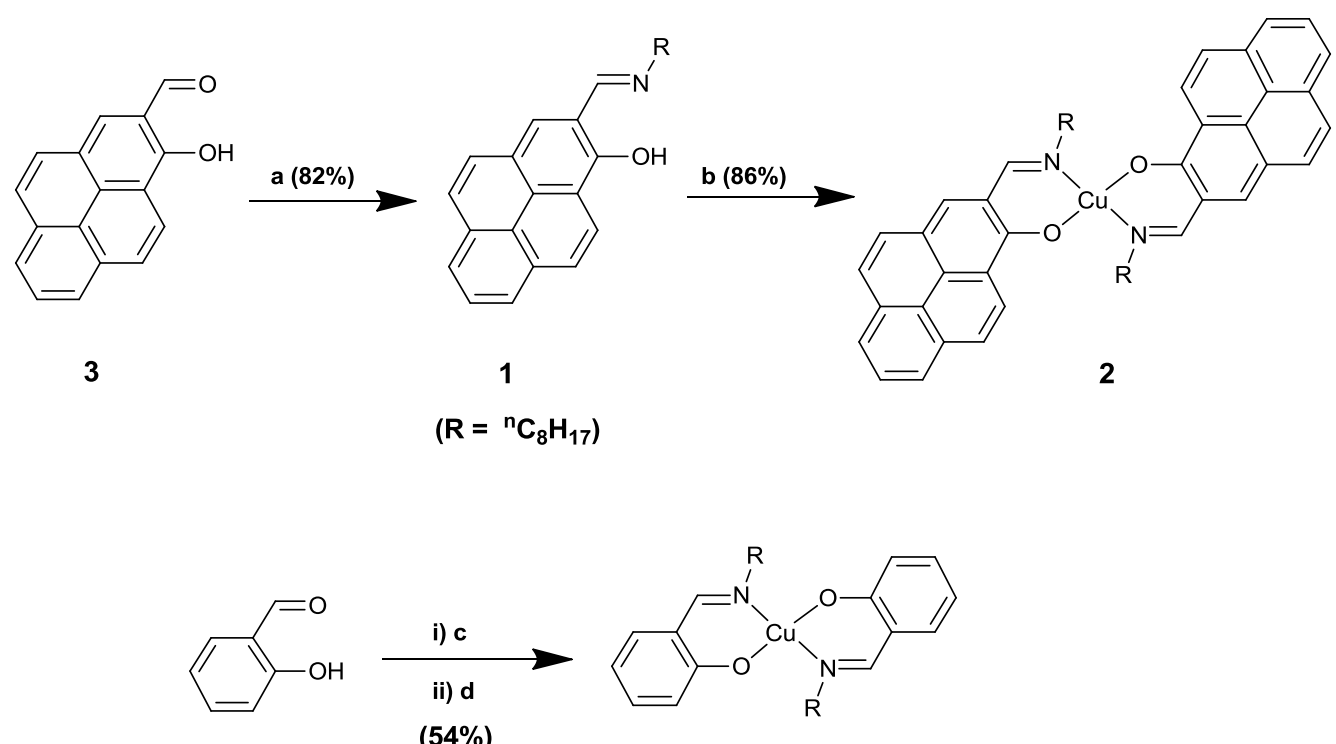

Salicylaldehyde

$\left(R={ }^{n} C_{3} H_{7}\right)$

Scheme 1. Syntheses of the pyrene-based ligand 1, its copper complexes 2 and the reference copper complex $3^{a}$

a(a) n-octylamine, $\mathrm{CH}_{2} \mathrm{Cl}_{2}$, r.t., $1 \mathrm{~h}$; (b) $\mathrm{Cu}\left(\mathrm{CH}_{3} \mathrm{COO}\right)_{2} \cdot \mathrm{H}_{2} \mathrm{O}, \mathrm{CH}_{3} \mathrm{COONa}$, 5:1 PhMe:EtOH, $60^{\circ} \mathrm{C}, 3 \mathrm{~h}$; (c) $\mathrm{Cu}\left(\mathrm{CH}_{3} \mathrm{COO}\right)_{2} \cdot \mathrm{H}_{2} \mathrm{O}, 1: 1$ ethanol: $\mathrm{H}_{2} \mathrm{O}$, r.t., $1 \mathrm{~h}$; (d) n-propylamine, ethanol, $85^{\circ} \mathrm{C}, 1 \mathrm{~h}$.

\subsection{Diffraction study}

The molecular structures of the complex 2 was established by single crystal X-ray diffraction. Additionally, the reference complex $4\left(\mathrm{R}={ }^{\mathrm{n}} \mathrm{C}_{8} \mathrm{H}_{17}\right)$ was presented to compare their structural characterizations [31]. The structures of the two complexes are shown in Figure 1. Details of the crystallization procedures can be found in the experimental section, while full CIFs are accessible in the SI and the relevant reference.

The crystal structure of $\mathbf{2}$ is in the P-1 space group, whereas the crystal structure of $\mathbf{4}$ is in the $\mathrm{P} 21 / \mathrm{c}$. In general, a paramagnetic copper(II) complex has a square planar geometry or tetrahedral geometry around copper [32]. In this research, these complexes $\mathbf{2}$ and $\mathbf{4}$ have the coordination of a square planar geometry around copper with no deflection from planarity. The four coordination sites are occupied by the two imines and the pyrenolate groups for $\mathbf{2}$ and phenolate groups for $\mathbf{4}$. For the complex $\mathbf{2}$, the
$\mathrm{Cu}-\mathrm{N}$ bonds were recorded at 2.0006(19) $\AA$ while the $\mathrm{Cu}-\mathrm{O}$ distances are at 1.9161(16) $\AA$.

Both complexes $\mathbf{2}$ and $\mathbf{4}$ are not co-planar, but are stepped as commonly seen in similar molecules, i.e. the two benzene rings are parallel, but their planes are separated by $0.74 \AA$ [38]. In $\mathbf{2}$, the two pyrene rings are also parallel and their planes are separated by $1.94 \AA$, approximately 3 times as much as that in $\mathbf{4}$. Therefore, the dihedral angle between pyrene ring and the plane of $\mathrm{N} 1-\mathrm{O} 1-\mathrm{O} 1^{\mathrm{i}}-\mathrm{N} 1^{\mathrm{i}}$ was measured at $34.9^{\circ}$, about 2 times as much as that in $4\left(15.9^{\circ}\right)$. Another notable point is that the plane of seven carbon atoms of the long alkyl chains of $\mathbf{2}$ is nearly parallel to pyrene ring $\left(6.7^{\circ}\right)$ whereas the plane of eight carbon atoms of the long alkyl chains of 4 is co-planar $\left(75.2^{\circ}\right)$. This difference can be caused by the fact that pyrene is bigger in size and has more $\pi$-electron that created the interaction $\mathrm{CH}-\pi$. The optimized structures of both complexes $\mathbf{2}$ and $\mathbf{4}$ were performed by Gaussian software in ground state. Table 2 displays some selected geometric parameters for 
each optimized structure together with the available experimental data from X-ray diffraction analysis [31]. As a whole, there is a perfect harmony between the theoretical data and the experimental structure for the ground state.

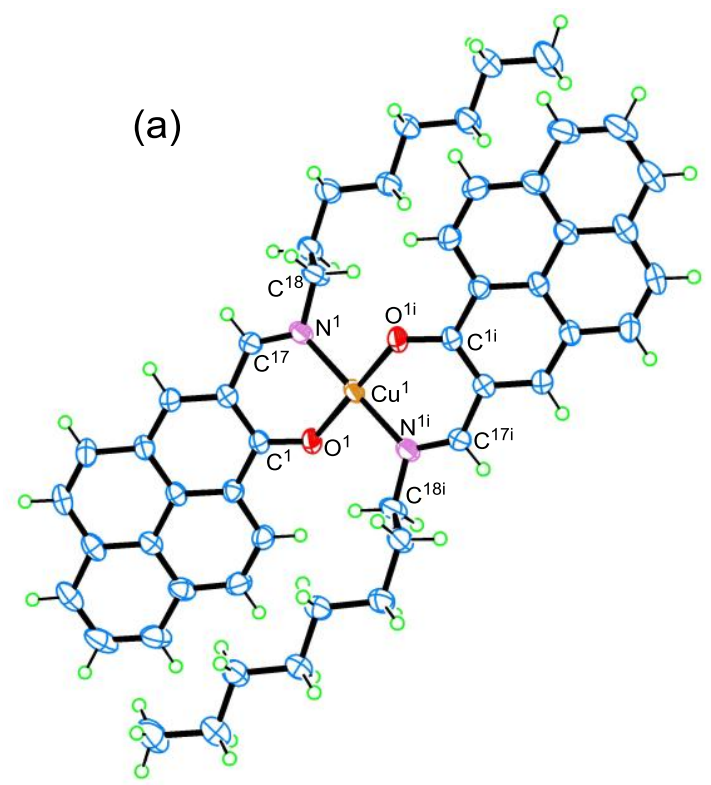

(b)

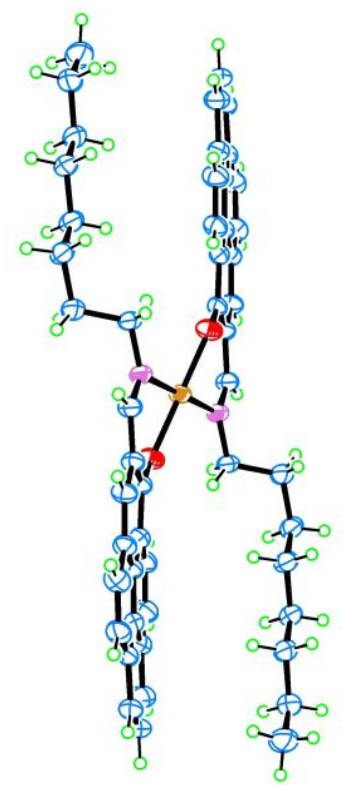

(c)

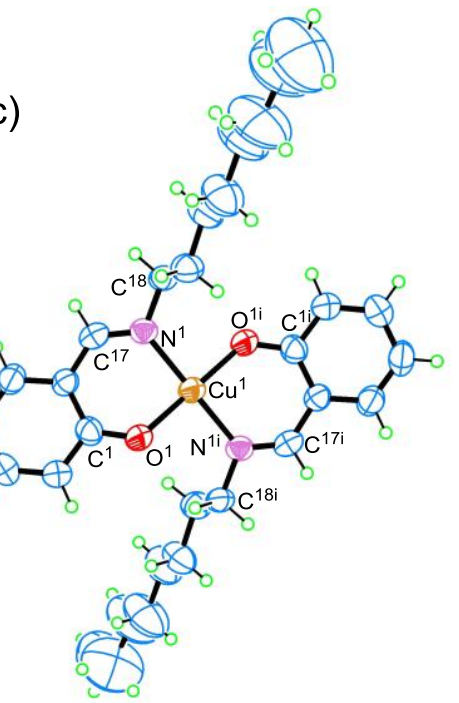

(d)

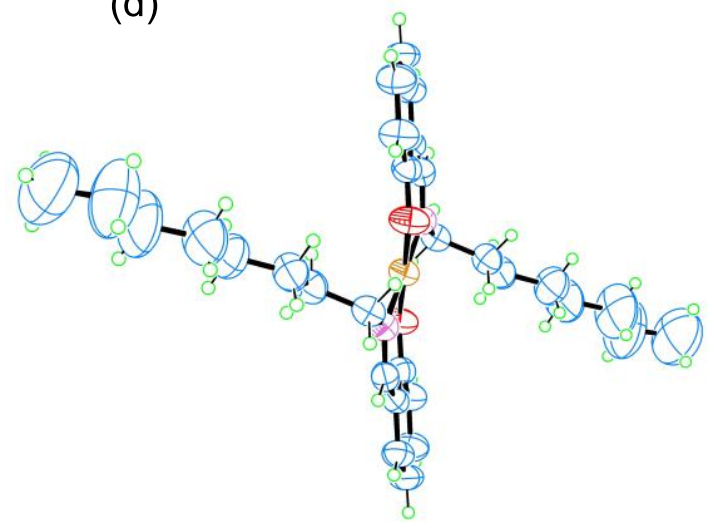

Figure 1. ORTEP view of the two complexes $\mathbf{2}$ and $\mathbf{4}$ as obtained by single crystal X-ray diffraction: (a) $\mathbf{2}$ top view, (b) 2 side view, (c) 4 top view, and (d) 4 side view. Atomic displacement ellipsoids are drawn at the 50\% probability level. Element (color): copper (copper), carbon (blue), nitrogen (purple), oxygen (red) and hydrogen (yellow green). 
Table 1. Crystal data and structure refinement details for $\mathbf{2}$ and $\mathbf{4}$

\begin{tabular}{|c|c|c|}
\hline & $2\left(\mathrm{R}={ }^{\mathrm{n}} \mathrm{C}_{8} \mathrm{H}_{17}\right)$ & $4\left(\mathrm{R}={ }^{\mathrm{n}} \mathrm{C}_{8} \mathrm{H}_{17}\right)^{31}$ \\
\hline Mol. formula & $\mathrm{C}_{50} \mathrm{H}_{52} \mathrm{CuN}_{2} \mathrm{O}_{2}$ & $\mathrm{C}_{30} \mathrm{H}_{44} \mathrm{CuN}_{2} \mathrm{O}_{2}$ \\
\hline Mol. Weight & 776.52 & 528.21 \\
\hline Crystal habit & Brown, block & Brown, block \\
\hline Crystal dimens./mm & $0.280 \times 0.150 \times 0.060$ & $0.20 \times 0.20 \times 0.15$ \\
\hline Crystal system & Triclinic & Monoclinic \\
\hline Space group & P-1 & $\mathrm{P} 2{ }_{1} / \mathrm{c}$ \\
\hline$a(\AA)$ & $8.207(5)$ & $16.571(4)$ \\
\hline$b(\AA)$ & $9.704(6)$ & $9.742(3)$ \\
\hline$c(\AA)$ & $12.360(8)$ & $9.500(3)$ \\
\hline$\alpha(\operatorname{deg})$ & $97.720(8)$ & 90 \\
\hline$\beta(\operatorname{deg})$ & $98.191(11)$ & $101.507(5)$ \\
\hline$\gamma(\operatorname{deg})$ & $92.742(6)$ & 90 \\
\hline $\mathrm{V}\left(\AA^{3}\right)$ & $963.2(10)$ & $1502.9(7)$ \\
\hline $\bar{Z}$ & 1 & 2 \\
\hline$D_{\text {calcd }}\left(\mathrm{g} / \mathrm{cm}^{3}\right)$ & 1.339 & 1.167 \\
\hline$\mu(\operatorname{Mo~K} \alpha)\left(\mathrm{cm}^{-1}\right)$ & 6.117 & 7.500 \\
\hline $\mathrm{T} / \mathrm{K}$ & $298(1)$ & $298(2)$ \\
\hline $2 q_{\max }(\mathrm{deg})$ & 54.9 & 50 \\
\hline Radiation MoKa $(1=0.71075 \AA)$ & $\operatorname{MoK} \alpha$ & $\operatorname{MoK} \alpha$ \\
\hline $\mathrm{R} 1, \mathrm{wR} 2(\mathrm{I}>2 \sigma \mathrm{I})$ & $0.0459 / 0.1285$ & $0.048 / 0.126$ \\
\hline Measured Reflections & Total: $9691 \quad$ Unique: 4355 & Unique: 1414 \\
\hline $\mathrm{R}_{\text {int }}$ & 0.035 & 0.056 \\
\hline
\end{tabular}

The molecular packing diagrams for both complexes $\mathbf{2}$ and $\mathbf{4}$ are displayed in Figure 2. It is well-known that bis(N-alkylsalicylaldiminato) copper(II) complexes have supramolecular architectures depending on the chain length [3244]. With the complexes $\left(\mathrm{R}={ }^{\mathrm{n}} \mathrm{C}_{8} \mathrm{H}_{17}\right)$, they have several similar characters such as monomer, with long $\mathrm{Cu} \cdots \mathrm{Cu}$ separations of $8.207 \AA$ and $6.804 \AA$ for $\mathbf{2}$ and $\mathbf{4}$, respectively, long alkyl chains break $\pi-\pi$ interactions of the aromatic rings. However, the complex 2 has a more stair-step structure than the complex $\mathbf{4}$ as mentioned above. Another striking point is the different arrangements of the long alkyl chain in both complexes. In the complex 4, the eight carbon atoms of long alkyl chains are organized in columns along an axis, while the plane of seven carbon atoms of the long alkyl chains arranged nearly parallel to the pyrene rings in the complex 2 (Figure 2). In each cell unit, there are 4 and 10 complexes for 2 and 4, respectively. This can be understood as the expansion of $\pi$-system inducing the larger aromatic rings to increase the interactions of $\mathrm{CH}$ $\pi$.
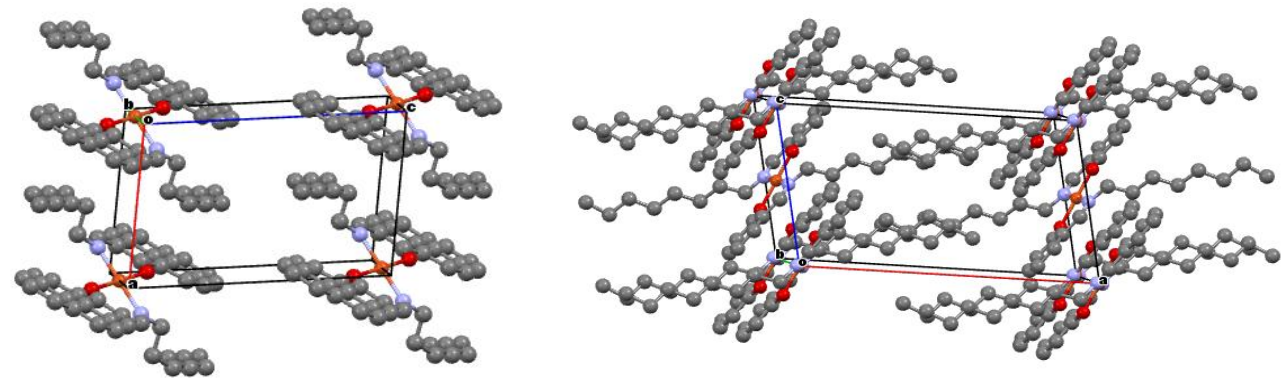

Figure 2. Crystal packings of the complexes $2\left(\mathrm{R}={ }^{\mathrm{n}} \mathrm{C}_{8} \mathrm{H}_{17}\right)$ (left) and $\mathbf{4}\left(\mathrm{R}={ }^{\mathrm{n}} \mathrm{C}_{8} \mathrm{H}_{17}\right)$ (right). Hydrogen atoms are omitted for clarity. 


\subsection{DFT calculations}

Table 2. Comparison of selected geometric parameters coming from X-ray diffraction analysis and DFT

\begin{tabular}{|c|c|c|c|c|c|}
\hline \multicolumn{3}{|c|}{$2\left(\mathrm{R}={ }^{\mathrm{n}} \mathrm{C}_{8} \mathrm{H}_{17}\right)$} & \multicolumn{3}{|c|}{$4\left(\mathrm{R}={ }^{\mathrm{n}} \mathrm{C}_{8} \mathrm{H}_{17}\right)$} \\
\hline & X-ray & $\begin{array}{l}\text { Optimized } \\
\text { geometry }\end{array}$ & & X-ray & $\begin{array}{l}\text { Optimized } \\
\text { geometry }\end{array}$ \\
\hline N1-Cu1 & $2.0006(19)$ & 1.96579 & $\mathrm{~N} 1-\mathrm{Cu} 1$ & $2.009(3)$ & 1.97358 \\
\hline $\mathrm{N} 1^{\mathrm{i}}-\mathrm{Cu} 1$ & $2.0006(19)$ & 1.96579 & $\mathrm{~N} 1{ }^{\mathrm{i}}-\mathrm{Cu} 1$ & $2.009(3)$ & 1.97358 \\
\hline $\mathrm{O} 1-\mathrm{Cu} 1$ & $1.9161(16)$ & 1.88824 & $\mathrm{O} 1-\mathrm{Cu} 1$ & $1.888(3)$ & 1.88513 \\
\hline $\mathrm{O} 1^{\mathrm{i}}-\mathrm{Cu} 1$ & $1.9161(16)$ & 1.88824 & $\mathrm{O} 1^{\mathrm{i}}-\mathrm{Cu} 1$ & $1.888(3)$ & 1.88513 \\
\hline $\mathrm{O} 1-\mathrm{C} 1$ & $1.306(3)$ & 1.30123 & $\mathrm{O} 1-\mathrm{C} 1$ & $1.305(5)$ & 1.30377 \\
\hline N1-C18 & $1.485(3)$ & 1.47453 & N1-C18 & $1.471(4)$ & 1.47419 \\
\hline N1-C17 & $1.285(3)$ & 1.29535 & N1-C17 & $1.288(5)$ & 1.29609 \\
\hline $\mathrm{O} 1^{\mathrm{i}}-\mathrm{Cu} 1-\mathrm{N} 1^{\mathrm{i}}$ & $89.54(7)$ & 94.69566 & $\mathrm{O} 1^{\mathrm{i}}-\mathrm{Cu} 1-\mathrm{N} 1^{\mathrm{i}}$ & $91.09(13)$ & 94.75246 \\
\hline O1-Cu1-N1 & $89.54(7)$ & 94.69566 & O1-Cu1-N1 & $91.09(13)$ & 94.75246 \\
\hline $\mathrm{O} 11^{\mathrm{i}}-\mathrm{Cu} 1-\mathrm{N} 1$ & $90.46(7)$ & 95.16176 & $\mathrm{O} 1^{\mathrm{i}}-\mathrm{Cu} 1-\mathrm{N} 1$ & $88.91(13)$ & 94.34646 \\
\hline $\mathrm{O} 1-\mathrm{Cu} 1-\mathrm{N} 1^{\mathrm{i}}$ & $90.46(7)$ & 95.16176 & $\mathrm{~N} 1-\mathrm{Cu} 1-\mathrm{N} 1^{\mathrm{i}}$ & $88.91(13)$ & 94.34646 \\
\hline
\end{tabular}

\subsection{IR spectroscopy}

The characteristic behavior was observed in IR spectra, i.e., the lower-frequency shift of the imine $\mathrm{C}=\mathrm{N}$ stretching mode $\left(v_{\mathrm{CN}}\right)$ attributable to the complex formation [33-35]. The IR spectra of both complexes $\mathbf{2}$ and $\mathbf{4}$ are shown in Figure 3 . The intense $v_{\mathrm{CN}}$ signal of $\mathbf{1}, 1623 \mathrm{~cm}^{-1}$, was shifted to lower frequency region in $2,1616 \mathrm{~cm}^{-}$ ${ }^{1}$. $\pi$-expansion only influences the $v_{\mathrm{CN}}$ of $\mathbf{2}$ as the lower frequency shift [37]. The value of the salicylaldimine ligand $\left(\mathrm{R}={ }^{\mathrm{n}} \mathrm{C}_{8} \mathrm{H}_{17}\right.$ is $1634 \mathrm{~cm}^{-1}$. The complex $4\left(\mathrm{R}={ }^{\mathrm{n}} \mathrm{C}_{3} \mathrm{H}_{7}\right)$ presents the smaller value, $1626 \mathrm{~cm}^{-1}$, than that of complex 2 . This datum also shows the effect of $\pi$-expansion on the $v_{\mathrm{CN}}$. Reflecting the pyrene nucleus of $\mathbf{1}$ and 2, several strong absorptions attributable to $\mathrm{C}-\mathrm{H}$ out-of-plane vibrations of pyrene, $\gamma_{\mathrm{CH}}$, were discovered in the frequency range of 850-680 $\mathrm{cm}^{-1}$ [37]. Because the IR spectra of symmetrical $\left(\mathrm{C}_{2}\right)$ pyrene derivatives can be perfectly reflected by theoretical calculations in terms of both the energies and intensities of bands, calculated IR spectra were gained for both complexes $\mathbf{2}$ and $\mathbf{4}$ and compared with the experimental data for these complexes. As seen from Figure 3, the calculated spectra for both complexes $\mathbf{2}$ and $\mathbf{4}$ perfectly reproduced the experimental data. Especially, we focused on the $1700-1500 \mathrm{~cm}^{-1}$ region and $1000-500 \mathrm{~cm}^{-1}$ region where complexes 2 show the intense characteristic peaks at 1616, 841, and $686 \mathrm{~cm}^{-1}$. As clearly shown in Figure 3, these three intense peaks were reproduced for $\mathbf{2}$ and only one intense peak of $v_{\mathrm{CN}}$ was also reproduced for 4 . Thus, these results show that $\pi$-expansion has an effect on the vibrations in these molecules.

\subsection{Absorption Spectra}

The absorption spectra of both complexes are displayed in the region of $300-800 \mathrm{~nm}$ region in Figure 4. The lowest excitation observed at $483 \mathrm{~nm}$, was substantially bathochromic shifted into the visible region relative to that of $\mathbf{4}$, was appointed to be the $\pi-\pi^{*}$ transition, based on theoretical studies, showing the expansion of the aromatic $\pi$ systems of $\mathbf{2}$ relative to the complex 4. The spectrum of $\mathbf{2}$ with fine structures might be the similar behavior of those for aromatic compounds such as pyrene [24]. 
The calculated absorption spectra based on the complexes $2\left(\mathrm{R}={ }^{\mathrm{n}} \mathrm{C}_{8} \mathrm{H}_{17}\right)$ and $\mathbf{4}\left(\mathrm{R}={ }^{\mathrm{n}} \mathrm{C}_{3} \mathrm{H}_{7}\right)$ are also shown in the bottom portion of Figure 3 (for details, see the table 3 and 4). It can be easily seen that the experimental data and the theoretical data are in a good harmony.

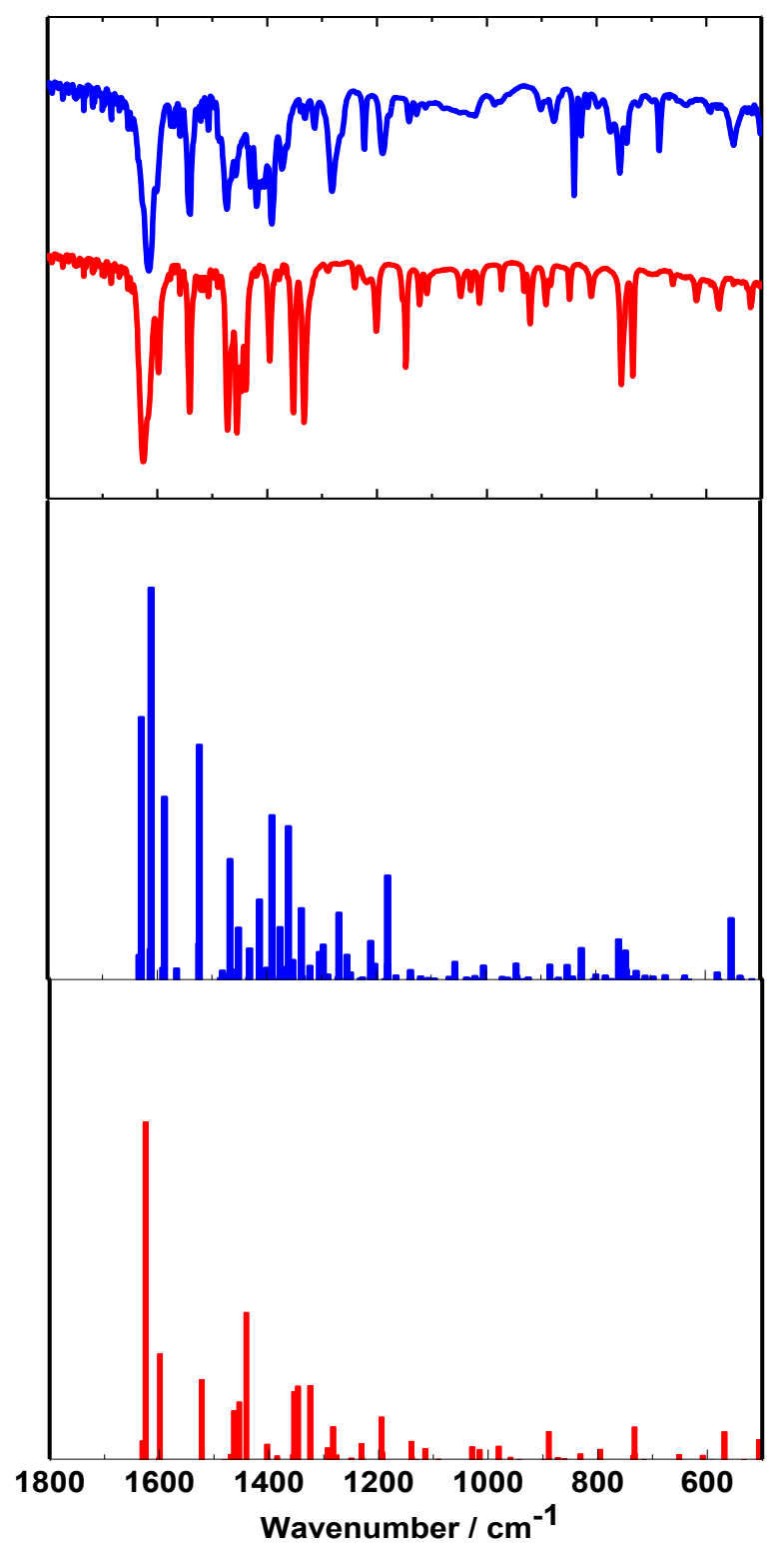

Figure 3. Observed IR spectra (top) of both complexes 2 (blue) and $\mathbf{4}$ (red) and theoretical IR spectra (bottom) of $2\left(\mathrm{R}={ }^{\mathrm{n}} \mathrm{C}_{8} \mathrm{H}_{17}\right)$ (blue) and $4\left(\mathrm{R}={ }^{\mathrm{n}} \mathrm{C}_{3} \mathrm{H}_{7}\right)$ (red).

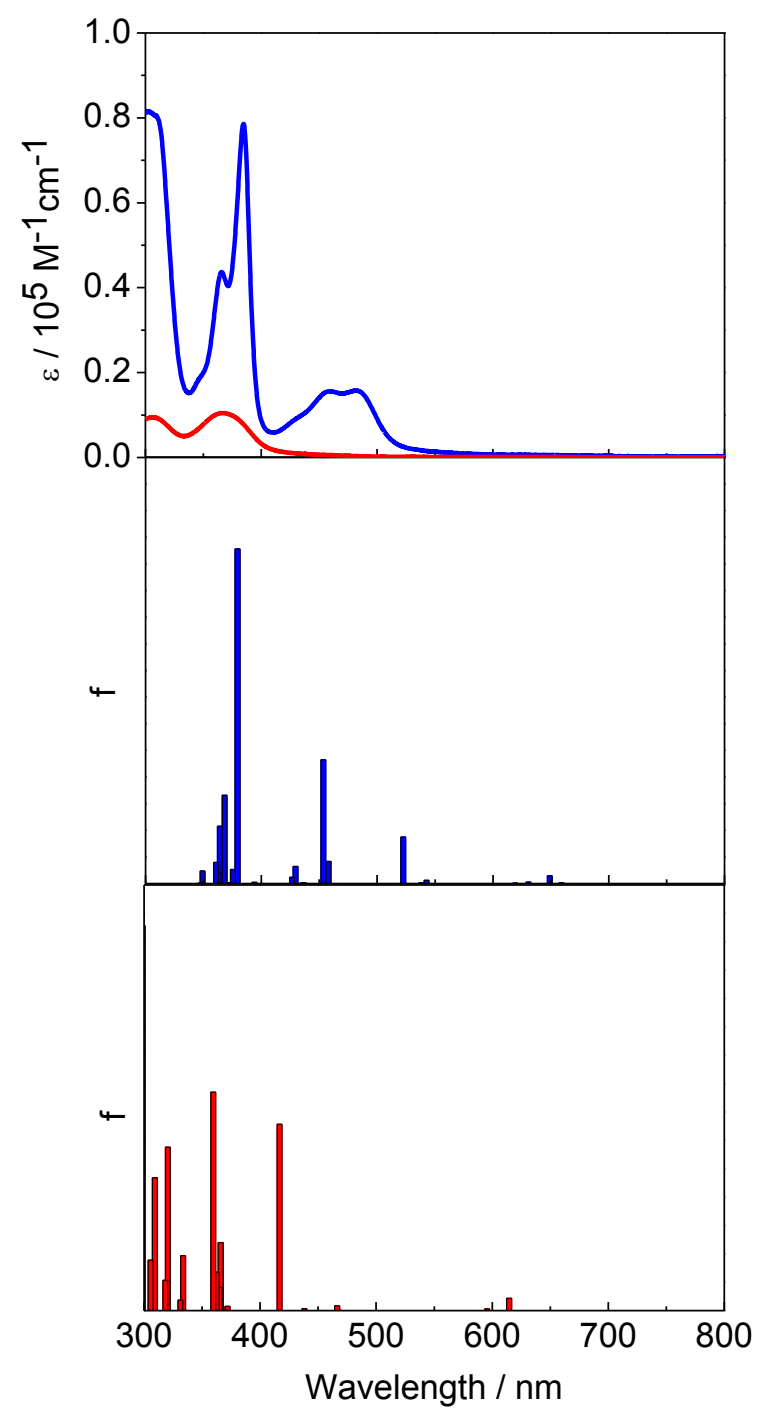

Figure 4. Absorption spectra (top) of both complexes 2 (blue) and 4 (red) in toluene and theoretical absorption spectra (bottom) of $2\left(\mathrm{R}={ }^{\mathrm{n}} \mathrm{C}_{8} \mathrm{H}_{17}\right)$ (middle - blue) and $4\left(\mathrm{R}={ }^{\mathrm{n}} \mathrm{C}_{3} \mathrm{H}_{7}\right)$ (bottom - red).

\subsection{Analysis of $\pi$-electron structure}

Theoretical calculations were executed using the Gaussian 09 software package $[38,42]$ in order to provide deeper understandings of the electronic structures. Geometry optimizations of the ground states of both complexes were achieved using density functional theory (DFT) at the UB3LYP/6-31G(d) level of theory. The 
optimized structures were characterized by vibration frequencies calculations. These optimized structures are very uniform to the crystal structures of $\mathbf{2}$ and $\mathbf{4}$ (Table 2). In addition, the theoretical absorption spectra (Figure 4) and a beta molecular orbital (MO) diagram (Figure 5) were calculated for both complexes using time-dependent density functional theory (TD-DFT) at the UB3LYP/6$31 \mathrm{G}(\mathrm{d})$ level of theory to observe the effect of $\pi$ expanded system on the electronic structures. The lowest energy transitions of both complexes are summarized in Tables 3 and 4. In Figure 3, the absorption of $\mathbf{2}$ and $\mathbf{4}$ was predicted at 522; $453 \mathrm{~nm}$ and 417; $366 \mathrm{~nm}$, respectively. Therefore, it can be concluded that the $\pi$ expansion affects the red shift of the absorption spectrum. In Figure 5, the $\beta$-HOMO of 2 is far higher in energy than that of $4(-4.73 \mathrm{eV}$ instead of $5.21 \mathrm{eV}$ ) and the $\beta$-LUMO of $\mathbf{2}$ is also far lower in energy than that of $\mathbf{4}(-2.15 \mathrm{eV}$ instead of $-1.87 \mathrm{eV}$ ). Thus, the $\beta$ HOMO- $\beta$ LUMO gap of $\mathbf{2}$ is much smaller than that of $\mathbf{4}(2.58 \mathrm{eV}$ instead of $3.34 \mathrm{eV}$ ). The marked red shift of the absorption of $\mathbf{2}$ relative to that of $\mathbf{4}$ is readily justified on this basis [38].

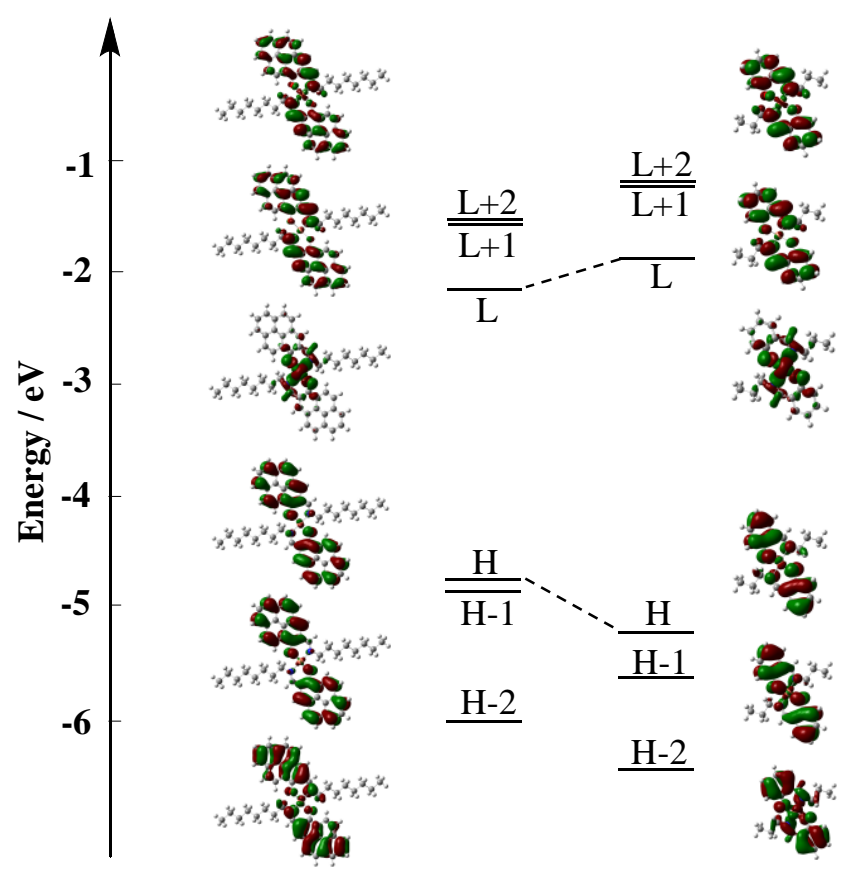

Figure 5. $\beta$-MO diagrams of 2 and 4. $\mathrm{H}$ and $\mathrm{L}$ indicate the $\beta$-HOMO and $\beta$-LUMO, respectively.

Table 3. Lowest-energy transitions of the complex $2\left(\mathrm{R}={ }^{\mathrm{n}} \mathrm{C}_{8} \mathrm{H}_{17}\right)$ as calculated by the TD-DFT with UB3LYP functional and 6-31G(d) basis set in toluene (300-700 $\mathrm{nm}, f \geq 0.01$, transition contribution $\geq 14 \%$ )

\begin{tabular}{|c|c|c|lc|}
\hline Excitation state & Energy $(\mathrm{nm})$ & Oscillator strength $(f)$ & \multicolumn{2}{|c|}{ Dominant component } \\
\hline 3 & 649 & 0.0148 & HOMO-12 (B) $\rightarrow$ LUMO (B) & $(17 \%)$ \\
\hline 10 & 522 & 0.0873 & HOMO (B) $\rightarrow$ LUMO (B) & $(38 \%)$ \\
\hline 11 & 458 & 0.0415 & $\begin{array}{l}\text { HOMO (A) } \rightarrow \text { LUMO+1 (A) } \\
\text { HOMO (B) } \rightarrow \text { LUMO+1 (B) }\end{array}$ & $\begin{array}{l}(37 \%) \\
(50 \%)\end{array}$ \\
\hline 12 & 453 & 0.2324 & $\begin{array}{l}\text { HOMO (A) } \rightarrow \text { LUMO (A) } \\
\text { HOMO (B) } \rightarrow \text { LUMO+2 (B) }\end{array}$ & $\begin{array}{l}(37 \%) \\
(47 \%)\end{array}$ \\
\hline
\end{tabular}




\begin{tabular}{|c|c|c|c|c|}
\hline 15 & 429 & 0.032 & $\begin{array}{l}\text { HOMO-1 (A) } \rightarrow \text { LUMO+1 (A) } \\
\text { HOMO-1 (B) } \rightarrow \text { LUMO+1 (B) }\end{array}$ & $\begin{array}{l}(21 \%) \\
(62 \%)\end{array}$ \\
\hline 16 & 426 & 0.0116 & $\begin{array}{l}\text { HOMO-1 (A) } \rightarrow \text { LUMO (A) } \\
\text { HOMO-1 (B) } \rightarrow \text { LUMO+2 (B) }\end{array}$ & $\begin{array}{l}(14 \%) \\
(70 \%)\end{array}$ \\
\hline 19 & 379 & 0.6279 & $\begin{array}{l}\text { HOMO (A) } \rightarrow \text { LUMO+3 (A) } \\
\text { HOMO (B) } \rightarrow \text { LUMO+4 (B) }\end{array}$ & $\begin{array}{l}(38 \%) \\
(49 \%)\end{array}$ \\
\hline 20 & 375 & 0.0266 & $\begin{array}{l}\text { HOMO (A) } \rightarrow \text { LUMO+2 (A) } \\
\text { HOMO (B) } \rightarrow \text { LUMO+3 (B) }\end{array}$ & $\begin{array}{l}(33 \%) \\
(57 \%)\end{array}$ \\
\hline 24 & 368 & 0.1658 & HOMO-2 (B) $\rightarrow$ LUMO (B) & $(44 \%)$ \\
\hline 25 & 364 & 0.1076 & $\begin{array}{l}\text { HOMO-1 (A) } \rightarrow \text { LUMO+2 (A) } \\
\text { HOMO-1 }(\mathrm{B}) \rightarrow \text { LUMO+3 (B) }\end{array}$ & $\begin{array}{l}(20 \%) \\
(35 \%)\end{array}$ \\
\hline 27 & 363 & 0.0211 & HOMO (A) $\rightarrow$ LUMO+4 (A) & $(14 \%)$ \\
\hline 28 & 361 & 0.0398 & $\begin{array}{l}\text { HOMO-1 (A) } \rightarrow \text { LUMO+3 (A) } \\
\text { HOMO-1 (B) } \rightarrow \text { LUMO+4 (B) }\end{array}$ & $\begin{array}{l}(29 \%) \\
(49 \%)\end{array}$ \\
\hline 29 & 349 & 0.0237 & $\begin{array}{l}\text { HOMO-4 (A) } \rightarrow \text { LUMO+1 (A) } \\
\text { HOMO-2 (A) } \rightarrow \text { LUMO+1 (A) }\end{array}$ & $\begin{array}{l}(21 \%) \\
(53 \%)\end{array}$ \\
\hline
\end{tabular}

Table 4. Lowest-energy transitions of the complex $4\left(\mathrm{R}={ }^{\mathrm{n}} \mathrm{C}_{3} \mathrm{H}_{7}\right)$ as calculated by the TD-DFT with UB3LYP functional and 6-31G(d) basis set in toluene (300-700 nm, $f \geq 0.01$, transition contribution $\geq 14 \%$ )

\begin{tabular}{|c|c|c|lc|}
\hline Excitation state & Energy $(\mathrm{nm})$ & Oscillator strength $(f)$ & \multicolumn{3}{|c|}{ Dominant component } \\
\hline 8 & 417 & 0.0657 & $\begin{array}{l}\text { HOMO-4 (B) } \rightarrow \text { LUMO (B) } \\
\text { HOMO (B) } \rightarrow \text { LUMO (B) }\end{array}$ & $(39 \%)$ \\
\hline 11 & 366 & 0.0240 & $\begin{array}{l}\text { HOMO-2 (A) } \rightarrow \text { LUMO (A) } \\
\text { HOMO-1 (A) } \rightarrow \text { LUMO (A) }\end{array}$ & $\begin{array}{l}(18 \%) \\
(59 \%)\end{array}$ \\
\hline 13 & 363 & 0.0135 & $\begin{array}{l}\text { HOMO (A) } \rightarrow \text { LUMO (A) } \\
\text { HOMO (B) } \rightarrow \text { LUMO+1 (B) }\end{array}$ & $\begin{array}{c}(53 \%) \\
(33 \%)\end{array}$ \\
\hline 15 & 334 & 0.0194 & HOMO-1 (B) $\rightarrow$ LUMO+1 (B) & $(62 \%)$ \\
\hline 17 & 320 & 0.0576 & $\begin{array}{l}\text { HOMO-2 (A) } \rightarrow \text { LUMO (A) } \\
\text { HOMO-1 (A) } \rightarrow \text { LUMO (A) } \\
\text { HOMO-1 (B) } \rightarrow \text { LUMO+1 (B) }\end{array}$ & $\begin{array}{c}(16 \%) \\
(15 \%)\end{array}$ \\
\hline 18 & 318 & 0.0107 & $\begin{array}{l}\text { HOMO-2 (A) } \rightarrow \text { LUMO+1 (A) } \\
\text { HOMO-1 (A) } \rightarrow \text { LUMO+1 (A) } \\
(19 \%) \\
\text { HOMO-1 (B) } \rightarrow \text { LUMO+2 (B) }\end{array}$ & $(20 \%)$ \\
\hline 19 & 309 & 0.0468 & $\begin{array}{l}\text { HOMO-4 (B) } \rightarrow \text { LUMO (B) } \\
\text { HOMO-2 (B) } \rightarrow \text { LUMO (B) }\end{array}$ & $\begin{array}{l}(56 \%) \\
(32 \%)\end{array}$ \\
\hline 21 & 306 & 0.0178 & $\begin{array}{l}\text { HOMO (A) } \rightarrow \text { LUMO+2 (A) } \\
\text { HOMO (B) } \rightarrow \text { LUMO+4 (B) }\end{array}$ & $\begin{array}{l}(20 \%) \\
(17 \%)\end{array}$ \\
\hline
\end{tabular}

\subsection{Electrochemical properties}

Differential pulse voltammetry (DPV) and cylic voltammetry $(\mathrm{CV})$ of two complexes were performed in dry $0.1 \mathrm{M} \mathrm{PhCl}\left[\mathrm{n}-\mathrm{Bu}_{4} \mathrm{~N}\right] \mathrm{PF}_{6}$ supporting electrolyte with $\mathrm{Fc} / \mathrm{Fc}^{+}$as the reference redox couple (for details, see experimental section). The recorded voltammograms are shown in Figure 6 and summarized in Table 5 for the range within which redox processes were discovered. The complex 2 displays reversible first oxidation wave and three irreversible oxidation waves $(0.09 ; 0.57 ; 0.87$; and $1.07 \mathrm{~V})$ within the solvent window, while the complex $\mathbf{4}$ displays an irreversible first oxidation wave and another irreversible oxidation $(0.59$ and $0.86 \mathrm{~V})$. The HOMO-LUMO gaps for both complexes were established by the basis of the potential difference between the first oxidation and first 
reduction. From the voltammograms, the HOMO-LUMO gap of $\mathbf{2}(1.51 \mathrm{~V})$ is smaller than that of $4(2.04 \mathrm{~V})$, as foreseen from the bathochromic shift in absorption spectroscopy of 2 relative to 4 . The potential difference of 0.03 $\mathrm{V}$ between the first reduction steps of $\mathbf{4}(-1.45 \mathrm{~V})$ and $2(-1.42 \mathrm{~V})$ was smaller than the difference of $0.50 \mathrm{~V}$ between the first oxidation steps of these compounds $(0.59 \mathrm{~V}$ and $0.09 \mathrm{~V}$, respectively) (Figure 6). This is in agreement with the anticipation that the stabilization of the HOMO of $\mathbf{2}$ relative to the complex $\mathbf{4}$ is larger rather than destabilization of the LUMO (Figure 5). This is a result in line with the easier oxidation and reduction found experimentally for 2 compared with 4 . Therefore, the $\pi$ electronic-expanded system of pyrenyl moiety helps narrow HOMO-LUMO gap, and results in the longer conjugated system, the higher energy of the HOMO, and the lower energy of the LUMO. With a narrow HOMO-LUMO gap, the complex 2 requires less energy than the complex 4 in order to promote and electron from the HOMO to the LUMO, enabling the absorption of $\mathrm{UV}$ and visible light to take place at ever longer wavelength [38].

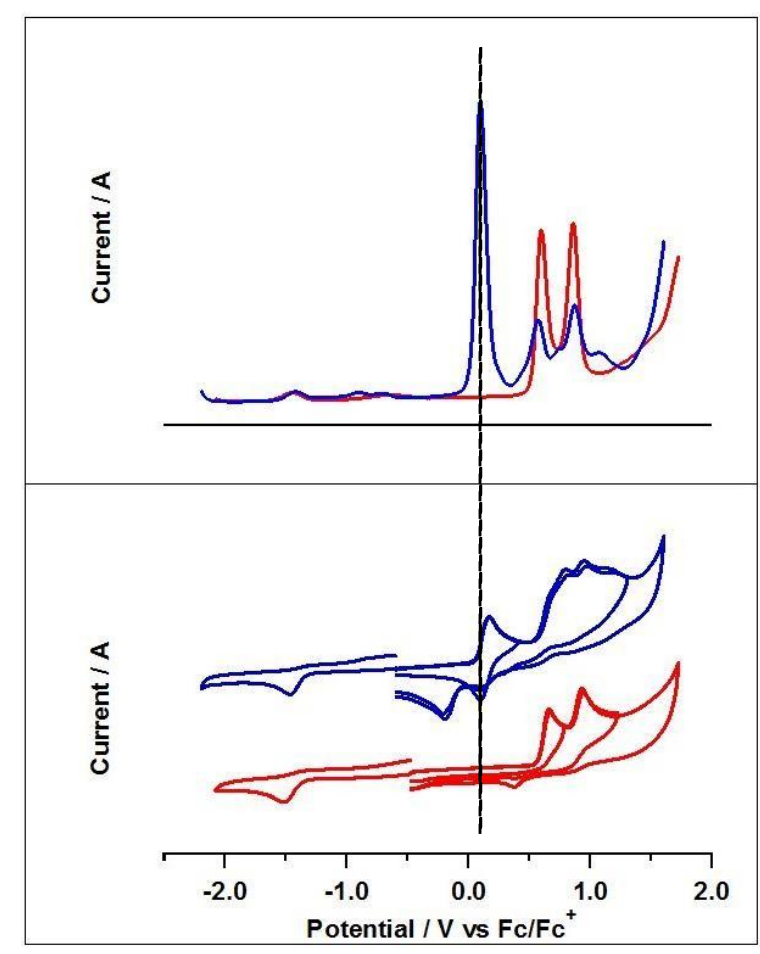

Figure 6. Room-temperature differential pulse voltammograms (top) and cyclic voltammograms (bottom) of both complexes 2 (blue lines) and $\mathbf{4}$ (red lines).

Table 5. Electrochemical data of the complexes $\mathbf{2}$ and $\mathbf{4}^{\text {a }}$

\begin{tabular}{|c|c|r|}
\hline Complexes & Oxidation & \multicolumn{1}{c|}{ Reduction } \\
\hline $\mathbf{2}$ & $+1.07(\mathrm{irr}),+0.87(\mathrm{irr}),+0.57(\mathrm{irr}),+0.09$ & -1.42 (irr) \\
\hline $\mathbf{4}$ & $+0.86(\mathrm{irr}),+0.59$ (irr) & -1.45 (irr) \\
\hline
\end{tabular}

${ }^{a} \mathrm{Ar}$-saturated $\mathrm{PhCN} / 0.1 \mathrm{M}\left[\mathrm{n}-\mathrm{Bu}_{4} \mathrm{~N}\right] \mathrm{PF}_{6}$, room temperature, $v=0.10 \mathrm{~V} \mathrm{~s}^{-1}$, glassy carbon working, platinum wire counter, and $\mathrm{Ag} / \mathrm{AgCl}$ reference electrodes, $\mathrm{E}_{1 / 2}$ for processes exhibiting peaks in the forward and back scans, peak potentials for processes, exhibiting no peak for the back scan (irr), presented in $\mathrm{V}$ vs. Fc/Fc ${ }^{+}$

\subsection{Magnetic studies}

Figure 7 shows temperature dependence of magnetic susceptibility $\chi_{\mathrm{A}}$ and effective magnetic moment $\mu_{\text {eff }}$ measured in magnetic field of $5000 \mathrm{Oe}$ as a function of temperature in the range of 2-300 $\mathrm{K}$ for the complex 2 in the solid state. The plot of $1 / \chi_{A}$ versus $T$ for $T>50$ $\mathrm{K}$ obeys the Curie-Weiss law, where the Weiss constant is the negative value of $\theta=-0.2 \mathrm{~K}$. In the range of the mentioned temperature, the effective magnetic moment $\mu_{\text {eff }}$ is in the range of 1.73-2.13 $\mu_{\text {B }}$ showing one unpaired electron, $\mathrm{a} \mathrm{d}^{9}$ configuration, on the copper center in the monomer complex 2 . The slight decrease of $\mu_{\mathrm{eff}}$ below $20 \mathrm{~K}$, the small value of the Weiss constant and the obtained coupling constant $\mathbf{J}=$ $0.0 \mathrm{~cm}^{-1}$ show no interaction between the copper monomers that is expected for the copper center separated by the large distance (> $8 \AA$ ) $[43,44]$. 


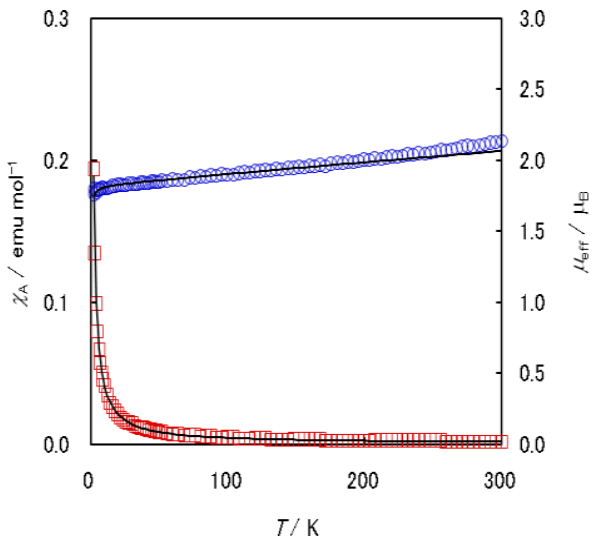

Figure 7. Temperature dependence of magnetic susceptibility $\chi_{A}$ (red line) and effective magnetic susceptibility $\mu_{\text {eff }}$ (blue line) as a function of temperature of the complex 2 measured in magnetic field of 5000 Oe.

Besides, the field dependence of the magnetization $(0-50 \mathrm{kOe})$ measured at $4.0 \mathrm{~K}$ is shown in Figure 8, where $\mathrm{M}, \mathrm{N}, \beta$ and $\mathrm{H}$ are magnetization, Avogadro's number, electron Bohr magneton and applied magnetic field, respectively. The magnetization increases with the increase of magnetic field, reaching ca. 0.73 $\mathrm{N} \beta$ per each the complex 2 at $50 \mathrm{kOe}$. Based on these things, it can be confirmed that the complex $\mathbf{2}$ is paramagnetic material.

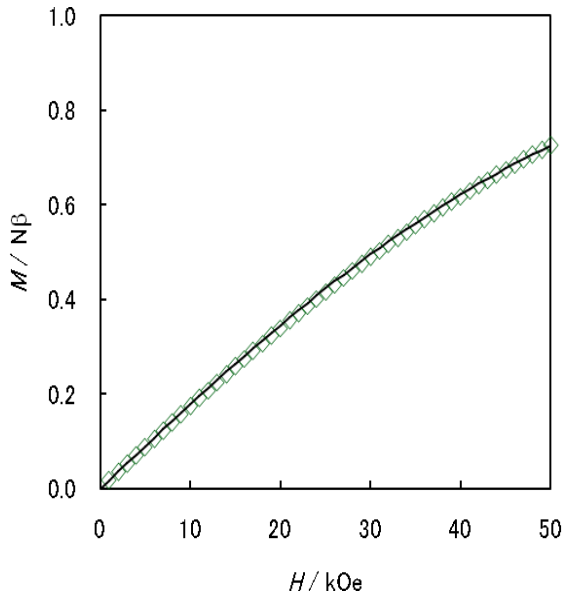

Figure 8. Magnetization for complex 2 at $4 \mathrm{~K}$ as a function of the applied magnetic field $(0-50 \mathrm{kOe})$.

\section{Conclusions}

A salicylaldiminato-type copper(II) complex of pyrene was designed and synthesized successfully by a six-step synthesis. The coordination of the ligand 1 to $\mathrm{Cu}$ (II) metal centre gave stable neutral square-planer complex 2, which was characterized by elemental analysis, IR spectroscopy, X-ray diffraction analysis, and magnetic susceptibility. The complex $\mathbf{2}$ is not co-planar, but is stepped as is commonly observed in similar complex 4 . However, the arrangement of carbon atoms of long alkyl chains is different in $\mathbf{2}$ and $\mathbf{4}$. In order to understand the electronic differences between the salicylaldiminato and the pyrene-based complexes, absorption spectroscopy, cyclic voltammetry experiments and comparative DFT study of $\mathbf{2}$ and $\mathbf{4}$ were performed. From these data, the effects of the expansion of $\pi$-system of the ligand certainly decreases the HOMOLUMO energy gap of the complex 2 . The lowest excitation energy found in the visible region and the lower oxidation potential and higher reduction potential observed at $0.09 \mathrm{~V}$ and -1.42 $\mathrm{V}$ of 2 , respectively, are applicable to the advanced materials such as organic solar cell. The packing of 2 exhibit no $\pi-\pi$ interaction in the network of the crystal structure that exists in mononuclear complex with the long distances of $\mathrm{Cu} \cdots \mathrm{Cu}$ separations. The authors are currently investigating other metal complexes with $\mathbf{1}$ and making some charge transfer complexes for $\mathbf{2}$. Besides, the authors are also considering the effect of the packing and coordination geometry of $\mathbf{2}$ to its photophysical properties and magnetic property.

\section{Experimental}

Synthesis. Preparation of 1 . To a solution of 3 (a yellow solid) (114.09 mg, $46 \mathrm{mmol}$ ) in $8 \mathrm{~mL}$ of $\mathrm{CH}_{2} \mathrm{Cl}_{2}$, a solution of $\mathrm{C}_{8} \mathrm{H}_{17} \mathrm{NH}_{2}(72.85 \mathrm{mg}$, $0.564 \mathrm{mmol})$ in $\mathrm{CH}_{2} \mathrm{Cl}_{2}(2 \mathrm{~mL})$ was added. The mixture was stirred at room temperature for $1 \mathrm{~h}$. Evaporation of the solvent gave $166.35 \mathrm{mg}$ of crude product, which was recrystallized from 
hexane to yield $\mathbf{1}$ as a red powder $(134.78 \mathrm{mg}, 82$ $\%$ ). $\mathrm{R}_{\mathrm{f}}=0.32$ (hexane/chloroform $=1: 3$ as eluent); Melting point (Mp): $98.5{ }^{\circ} \mathrm{C} ;{ }^{1} \mathrm{H}$ NMR $\left(500 \mathrm{MHz}, \mathrm{CDCl}_{3}\right) \delta 14.93(\mathrm{~s}, 1 \mathrm{H}), 8.71(\mathrm{~s}, 1 \mathrm{H})$, $8.53(\mathrm{~s}, 1 \mathrm{H}), 7.77-8.07(\mathrm{~m}, 7 \mathrm{H})$; IR(KBr) $\left(\mathrm{cm}^{-1}\right)$ $1623(\mathrm{C}=\mathrm{N})$. UV/vis $\left(\mathrm{CH}_{2} \mathrm{Cl}_{2}\right) \lambda_{\max } / \mathrm{nm}\left(\varepsilon / \mathrm{M}^{-1}\right.$ $\left.\mathrm{cm}^{-1}\right)$ : 526 (700), 430 (3,900), $408(3,200), 387$ $(3,400), \quad 357 \quad(21,700), \quad 342(15,200), \quad 324$ (shoulder, 7,400), and 274 (59,700). MS (MALDI) $(\mathrm{m} / \mathrm{z})$ : $\left[\mathrm{M}^{+}\right]$Calcd for $\mathrm{C}_{25} \mathrm{H}_{27} \mathrm{NO}$ : 357.50, Found 358.56, Anal.: Calcd for $\mathrm{C}_{25} \mathrm{H}_{27} \mathrm{NO}: \mathrm{C}, 83.99 ; \mathrm{H}, 7.61 ; \mathrm{N}, 3.92$. Found: $\mathrm{C}$, 83.70; H, 7.60; N, 3.81 .

Preparation of $\mathbf{2}$. A mixture of $\mathbf{1}(30.05 \mathrm{mg}$, $0.084 \mathrm{mmol})$, anhydrous $\mathrm{CH}_{3} \mathrm{COONa}(26.28 \mathrm{mg}$, $0.32 \mathrm{mmol}$ ) in $6 \mathrm{~mL}$ of mixture of toluene and ethanol $(\mathrm{PhMe} / \mathrm{EtOH}=5: 1)$ was added $\mathrm{Cu}\left(\mathrm{CH}_{3} \mathrm{COO}\right)_{2} \cdot \mathrm{H}_{2} \mathrm{O}(8.35 \mathrm{mg}, 0.042 \mathrm{mmol})$ at $60{ }^{\circ} \mathrm{C}$. The mixture was stirred for $3 \mathrm{~h}$. After a fast cool-down with an ice bowl, the reaction mixture was filtered and the residue was washed with methanol to obtain 2 as a yellow solid (26.64 mg, 82\%). Mp: $192{ }^{\circ} \mathrm{C}$; $\mathrm{IR}(\mathrm{KBr})\left(\mathrm{cm}^{-1}\right)$ $1616(\mathrm{C}=\mathrm{N}) . \mathrm{UV} / \mathrm{vis}\left(\mathrm{PhCH}_{3}\right) \lambda_{\max } / \mathrm{nm}\left(\varepsilon / \mathrm{M}^{-1} \mathrm{~cm}^{-}\right.$ $\left.{ }^{1}\right) 483(15,793), 460(15,599), 385(78,576), 366$ (shoulder, 43,689), 302(81,553). HR-MS (m/z): $\left[\mathrm{M}^{+}\right]$Calcd for $\mathrm{C}_{50} \mathrm{H}_{52} \mathrm{CuN}_{2} \mathrm{O}_{2}$, 776.34; Found: 776.34. Anal. Calcd for $\mathrm{C}_{50} \mathrm{H}_{52} \mathrm{CuN}_{2} \mathrm{O}_{2}: \mathrm{C}$, 77.34; H, 6.75; N, 3.61. Found: C, 77.17; H, $6.95 ; \mathrm{N}, 3.45$.

Preparation of 4 . The reference copper(II) salicylaldiminato has been prepared as is described in ref. 31. A cold concentrated solution of the $\mathrm{Cu}\left(\mathrm{CH}_{3} \mathrm{COO}\right)_{2} \cdot \mathrm{H}_{2} \mathrm{O}(0.5 \mathrm{mmol})$ in $3 \mathrm{~mL}$ of water was treated with the salicylaldehyde $(1 \mathrm{mmol})$ in ethanol $(3 \mathrm{~mL})$. The resulting suspension was heated on an oil-bath for $1 \mathrm{~h}$, cooled to room temperature, and filtered. The solid bis(salicylaldehydato) copper(II) was then refluxed in ethanol $(3 \mathrm{~mL})$ with an excess of n-propylamine $(1.35 \mathrm{mmol})$ in $1 \mathrm{~mL}$ of ethanol until solution was complete $(1 \mathrm{~h})$. The crystals 4 which separated on cooling were recrystallized from cyclohexane. (104.11 mg, 54\%). Mp: $122^{\circ} \mathrm{C}$; IR (KBr) $\left(\mathrm{cm}^{-1}\right) 1626(\mathrm{C}=\mathrm{N})$. UV/vis $\quad\left(\mathrm{PhCH}_{3}\right) \quad \lambda_{\max } / \mathrm{nm} \quad\left(\varepsilon / \mathrm{M}^{-1} \quad \mathrm{~cm}^{-1}\right) \quad 368$
(10,461), 308 (9,475). Anal.: Calcd for $\mathrm{C}_{20} \mathrm{H}_{24} \mathrm{~N}_{2} \mathrm{O}_{2} \mathrm{Cu}: \mathrm{C}, 61.92 ; \mathrm{H}, 6.24 ; \mathrm{N}, 7.22$. Found: C, 61.89; H, 6.20; N, 7.13.

\section{Appendix. Supplementary material}

CCDC 1953957 contains the supplementary crystallographic data for 2019/09/16. These data can be obtained free of charge via http://www.ccdc.cam.ac.uk/conts/retrieving.htm 1, or from the Cambridge Crystallographic Data Centre, 12 Union Road, Cambridge CB2 1EZ, UK; fax: (+44) 1223-336-033; or e-mail: deposit@ccdc.cam.ac.uk.

Three electronic supplementary informations (ESIs) are available: i.e., ESI-\#1: spectroscopic results, ESI-\#2: x-ray structure report, ESI-\#3: theoretical studies, and CIF-file of 2, CCDC 1953957. For ESIs and crystallographic data in CIF or another electronic format see DOI: XXXXXXXXXXX

\section{Acknowledgements}

This work was supported in part by the Priority Research Program sponsored by the Asian Human Resources Fund from Tokyo Metropolitan Government (TMG), and a National Foundation for Science \& Technology Development (NAFOSTED) grant funded by Vietnamese Ministry of Science and Technology (Grant No. 104.05-2017.26). L.X.D. appreciates to Tokyo Metropolitan University (TMU) for a pre-doctoral fellowship. The authors thank Prof. Masaaki Ohba (Kyushu University) for magnetic susceptibility, and Mr. Toshihiko Sakurai (TMU) for elemental analyses.

\section{References}

[1] D.J. Jones, V.C. Gibson, S.M. Green, P.J. Maddox, A.J.P. White, D.J. Williams, Discovery and optimization of new chromium catalysts for ethylene oligomerization and polymerization aided by high-throughput screening, J. Am. Chem. Soc. 127 (2005) 11037-11046. https://doi.org/10. 1021/ja0518171. 
[2] T. Wiedemann, G. Voit, A. Tchernook, P. Roesle, I.G. Schnetmann, S. Mecking, Monofunctional hyperbranched ethylene oligomers, J. Am. Chem. Soc. 136 (2014) 2078-2085. https://doi.org/10.10 21/ja411945n.

[3] N. Hoshino, Liquid crystal properties of metalsalicylaldimine complexes.: Chemical modifications towards lower symmetry, Coord. Chem. Rev. 174 (1998) 77-108. https://doi.org/10.1016/S0010-8545 (98)00129-5.

[4] C.K. Lai, C.H. Chang, C.H. Tsai, Liquid crystalline properties of bis (salicylaldiminato) copper(II) complexes: the first columnar discotics derived from salicylaldimine Schiff bases, J. Mater. Chem. 8 (1998) 599-602. https://doi.org/10.1039/A707091H.

[5] P. Wang, Z. Hong, Z. Xie, S. Tong, O. Wong, C.S Lee, N. Wong, L. Hung, S. Lee, A bissalicylaldiminato Schiff base and its zinc complex as new highly fluorescent red dopants for high performance organic electroluminescence devices, Chem. Commun. (2003) 1664-1665. https://doi.org/10.1039/B303591C.

[6] C.C. Kwok, S C. Yu, I.H.T. Sham, C.M. Che, Selfassembled zinc(ii) Schiff basepolymers for applications in polymer light-emitting devices, Chem. Commun. (2004) 2758-2759. https://doi. org/10.1039/B412762E

[7] M. Calvin, K.W. Wilson, Stability of Chelate Compounds, J. Am. Chem. Soc. 67 (1945) 2003 2007. https://doi.org/10.1021/ja01227a043.

[8] M. Calvin, N.C. Melchior, Stability of chelate compounds. IV. Effect of the metal ion, J. Am. Chem. Soc. 70 (1948) 3270-3273. https://doi.org/ 10.1021/ja01190a020.

[9] T.M.F. Duarte, K. Müllen, Pyrene-based materials for organic electronics, Chem. Rev. 111 (2011) 7260-7314. https://doi.org/10.1021/cr100428a.

[10] M. Shiotsuka, Y. Okaue, N. Matsumoto, H. Okawa, T. Isobe, Crystal structures and singlecrystal electron spin resonance spectra of $\pi-\pi$ type molecular complexes of bis(1-methyliminomethyl -2-naphtholato)copper(II), J. Chem. Soc., Dalton Trans. (1994) 2065-2070. https://doi.org/10.1039/ DT9940002065.

[11] K. Nishijima, T. Nozaki, H. Miyasaka, G. Mago, N. Matsumoto, The 1:2 and 1:4 $\pi$ - $\pi$ type molecular adducts of bis (N-alkyl-2-oxy-4-(1-naphthoyloxy) benzaldiminato) copper (II) and 1,3,5-trinitrobenzene, Inorganica Chimica Acta 234 (1995)131-137. https://doi.org/10.1016/0020-1693(95)04490-Z.
[12] C.W. Tang, Two-layer organic photovoltaic cell, Applied Physics Letters 48 (1986) 183-185. Http://adsabs.harvard.edu/abs/1986ApPhL..48..1 $83 \mathrm{~T}$.

[13] M. Hiramoto, M. Kubo, Y. Shinmura, N. Ishiyama, T. Kaji, K. Sakai, T. Ohno, M. Izaki, Bandgap science for organic solar cells, Electronics 3 (2014) 351-380. https://doi.org/10. 3390/electronics3020351.

[14] W. Leslie, R.A. Poole, P.R. Murray, L.J. Yellowlees, A. Beeby, J.A.G. Williams, Near infra-red luminescence from bis-terpyridyl iridium(III) complexes incorporating electron-rich pendants, Polyhedron 23 (2004) 2769-2777. https: //doi.org/10.1016/j.poly.2004.08.009.

[15] S. Faulkner, M.C. Carrié, S.J.A. Pope, J. Squire, A. Beeby, P.G. Sammes, Dalton Trans. (2004) 14051409. https://doi.org/10.1039/B401302F.

[16] S. Roy, S. Roy, S. Saha, R. Majumdar, R.R. Dighe, E.D. Jemmis, A.R. Chakravart, Cobalt(II) complexes of terpyridine bases as photochemotherapeutic agents showing cellular uptake and photocytotoxicity in visible light, Dalton Trans. 40 (2011) 1233. https://doi.org/10.1039/C0DT00223B.

[17] W. Wu, J. Sun, S. Ji, W. Wu, J. Zhao, H. Guo, Tuning the emissive triplet excited states of platinum(ii) Schiff base complexes with pyrene, and application for luminescent oxygen sensing and triplet-triplet-annihilation based upconversions, Dalton Trans. 40 (2011) 11550-11561. https://doi. org/10.1039/C1DT11001B.

[18] N.M. Cox, L.P. Harding, J.E. Jones, S.J.A. Pope, C.R. Rice, H. Adams, Probing solution behaviour of metallosupramolecular complexes using pyrene fluorescence, Dalton Trans. 41 (2012) 1568. https://doi.org/10.1039/C1DT11831E.

[19] J. Zhao, S. Ji, W. Wu, W. Wu, H. Guo, J. Sun, H. Sun, Y. Liu, Q. Li, L. Huang, Transition metal complexes with strong absorption of visible light and long-lived triplet excited states: from molecular design to applications, RSC Advances 2 (2012) 1712-1728. https://doi.org/10.1039/C1 RA00665G.

[20] R. Liu, N. Dandu, Y. Li, S. Kilina, W. Sun, Synthesis, photophysics and reverse saturable absorption of bipyridyl platinum(II) bis(arylfluorenylacetylide) complexes, Dalton Trans. 42 (2013) 4398-4409. https://doi.org/10.1039/C2DT32153J.

[21] A.S. Ionkin, William J. Marshall, Brian M. Fish, Synthesis and structural characterization of a series of novel polyaromatic ligands containing 
pyrene and related biscyclometalated iridium(III) complexes, Organometallics 25 (2006) 1461-1471. https://doi.org/10.1021/om0510775.

[22] W.Y. Heng, J. Hu, J.H.K. Yip, Attaching gold and platinum to the rim of pyrene: A synthetic and spectroscopic study, Organometallics 26 (2007) 6760. https://doi.org/10.1021/om700716p.

[23] Y.F. Han, H. Li, P. Hu, G.X. Jin, Alkyne insertion induced regiospecific $\mathrm{C}-\mathrm{H}$ activation with [Cp*MCl2]2 $(\mathrm{M}=\mathrm{Ir}, \mathrm{Rh})$, Organometallics 30 (2011) 905-911. https://doi.org/10.1021/om101064v.

[24] R.M. Edkins, K. Fucke, M.J.G. Peach, A.G. Crawford, T.B. Marder, A. Beeby, Syntheses, structures, and comparison of the photophysical properties of cyclometalated iridium complexes containing the isomeric 1- and 2-(2-pyridyl) pyrene ligands, Inorg. Chem. 52 (2013) 98429860. https://doi.org/10.1021/om101064v.

[25] X. Sun, Y.-W. Wang, Y. Peng, A selective and ratiometric bifunctional fluorescent probe for $\mathrm{Al}^{3+}$ ion and proton, Org. Lett. 14 (2012) 3420-3423. https://doi.org/10.1021/ol301390g.

[26] Luong Xuan Dien, Ken-ichi Yamashita, Motoko S. Asano, Ken-ichi Sugiura, Synthesis of a pyrenebased $\pi$-expanded ligand and the corresponding platinum(II) complex, Bis[2-[(octylimino) methyl] 1-pyrenolato-N,O] platinum(II), Inorganica Chimica Acta, 432 (2015) 103-108. https://doi.org/10.1016/ j.ica.2015.03.038.

[27] Luong Xuan Dien, Ken-ichi Yamashita, Ken-ichi Sugiura, Metal Complexes of $\pi$-Expanded Ligands (2): Synthesis and characterizations of bis[2-[(octylimino)methyl]-1-pyrenolato-N,O] palladium(II) and the stabilized vacant $\mathrm{dx}^{2}-\mathrm{y}^{2}$ orbital, Polyhedron, 102 (2015) 69-74. https://doi. org/10.1016/j.poly.2015.07.043.

[28] Luong Xuan Dien, Nguyen Xuan Truong, Ngo Duc Quan, Ken-ichi Yamashita, Ken-ichi Sugiura, Syntheses and structures of $\mathrm{Ni}(\mathrm{II})$ complexes containing 2 alkyliminomethyl pyrene ligands, VNU Journal of Science 34 (4) (2018) 16-20. https://doi.org/10.25073/2588-1140/vnunst.4809.

[29] Luong Xuan Dien, Nguyen Kim Nga, Nguyen Xuan Truong, Ken-ichi Yamashita and Ken-ichi Sugiura, Metal Complexes of $\pi$-Expanded Ligands (3): Synthesis and characterizations of tris[2-[(octylimino)methyl]-1-pyrenolato-N,O] cobalt(III), VNU Journal of Science 35 (2) (2019) 98-105. https://doi.org/10.25073/2588-1140/vnunst. 4898.
[30] P. Demerseman, J. Einhorn, J.F. Gourvest, R. Royer, Synthèse d'analogues furanniques du benzo[a]pyrene, J. Heterocycl. Chem. 22 (1985) 39-43. https://doi.org/10.1002/jhet.5570220110.

[31] L.Z. Zhang, P.Y. Bu, L.J. Wang, P. Cheng, Bis(Noctylsalicylideniminato-N,O)copper(II), Acta Cryst. C57 (2001) 1166-1167. http://scripts.iucr. org/cgi-bin/paper?-S0108270101013154.

[32] L. Sacconi, M. Ciampolini, 45. Pseudo-tetrahedral structure of some $\alpha$-branched copper(II) chelates with Schiff bases, J. Chem. Soc., 1964, 276-280. https://doi.org/10.1039/JR9640000276.

[33] P. Teyssie, J.J. Charette, Physico-chemical properties of co-ordinating compounds-III: Infrared spectra of $\mathrm{N}$-salicyclidenealkylamines and their chelates, Spectrochim. Acta 19 (1963) 1407-1423. https://doi.org/10.1016/0371-1951(63) 80003-X.

[34] J.E. Kovacic, The C-N stretching frequency in the infrared spectra of Schiff's base complexes-I. Copper complexes of salicylidene anilines, Spectrochim. Acta, Part A 23 (1967) 183-187. https://doi.org/10.1016/0584-8539(67)80219-8.

[35] N.V. Tverdova, N.I. Giricheva, G.V. Girichev, N.P. Kuz'mina, O.V. Kotova, A.V. Zakharov, IR Spectra of N,N'-Ethylene-Bis(salicylaldiminates) and N,N-ethylene- Bis(acetylacetoniminates) of $\mathrm{Ni}(\mathrm{II}), \mathrm{Cu}(\mathrm{II})$, and Zn(II), Russ. J. Phys. Chem. A 83 (2009) 2255-2265. https://doi.org/10.1134/ S0036024409130135.

[36] J.D. Goulden, The Infrared spectra of quaternary methiodides of NN-disubstituted thioamides, J. Chem. Soc. (1953) 997-998. https://doi.org/10. 1039/JR9530000996.

[37] P.E. Hansen, A. Berg, Infrared Spectra of Pyrene Derivatives. Relation to the Substitution Pattern., Acta Chem. Scand., Ser. B35 (1981)131-137. http://actachemscand.org/pdf/acta_vol_35b_p013 1-0137.pdf.

[38] Ian Fleming, Molecular Orbitals and Organic Chemical Reactions, Wiley, United Kingdom, 2009, pp 31.

[39] D. Hall, R.H. Sumner, T.N. Waters, The colour isomerism and structure of copper co-ordination compounds. Part XVIII. The crystal structure of bis-(N-n-butylsalicylaldiminato)-copper(II), J. Chem. Soc. A (1969) 420-422. https://doi.org/10.1039/ J19690000420.

[40] G.M. Sheldrick, SHELXL-97: Program for the Solution and Refinement of Crystal Structures; University of Göttingen: Göttingen, Germany, 1997. 
[41] P.J. Hay, W.R. Wadt, Ab initio effective core potentials for molecular calculations. Potentials for the transition metal atoms Sc to $\mathrm{Hg}$, J. Chem. Phys. 82 (1985) 299. https://doi.org/10.1063/1. 448799.

[42] M.J. Frisch; et al. Gaussian 09, Revision A.1; Wallingford, CT, 2009.

[43] E. Safaei, M.M. Kabir, A. Wojtczak, Z. Jaglicic, A. Kozakiewicz, Y. I. Lee, Synthesis, crystal structure, magnetic and redox properties of copper(II) complexes of $\mathrm{N}$-alkyl(aryl) tBusalicylaldimines, Inorganica Chimica Acta 366
(2011) 275-282. https://doi.org/10.1016/j.ica.2010. 11.017 .

[44] A. Ríos-Escudero, M. Villagrán, F. Caruso, J.P. Muena, E. Spodine, D. Venegas-Yazigi, L. Massa, L.J. Todaro, J. H. Zagal, G.I. Cárdenas-Jirón, M. Páez, J. Costamagna, Electrocatalytic reduction of carbon dioxide induced by bis(N-R-2-hydroxy-1naphthaldiminato)-copper(II) ( $\mathrm{R}=\mathrm{n}$-octyl, $\mathrm{n}$ dodecyl): Magnetic and theoretical studies and the $\mathrm{X}$-ray structure of bis(N-n-octyl-2-hydroxy-1naphthaldiminato)-copper(II), Inorganica Chimica Acta 359 (2006) 3947-3953. https://doi.org/10. 1016/j.ica.2006.04.027. 